\title{
THE KOLONIAL INSTITUT OF HAMBURG *
}

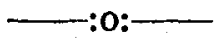

- [Because of the importance of the language problem in Missions to Moslems, we welcome this brief article on one of the most celebrated language-schools in Europe.-ED.]

IN 1884 Germany appeared as a colonial power. In October, 1908, the City of Hamburg opened an institution for the special purpose of preparing public officials and private individuals for service in forcign parts. Similar undertakings had been contemplated or variously carried out elsewhere; but the Hamburgisches Kolonialinstitut is unique in the boldness of its conception and the thoroughness of its organization. All such as have to do with the expansion and development of the German colonies-officials, missionaries, merchants, planters, travellers and scientific investigators - were to have the conceivably best preparation for their tasks. More than this, it was to invite foreign students to study in Hamburg and acquaint themselves with German science and German colonial problems, and create in the European home countries an intelligently sympathetic publikum. which might be relied on to favour the colonies with sound legislation and enterprising settlers. German universities, libraries and museums offered in a scattered way more than probably could have been found in any other country ; in Berlin existed the Seminar für Orientalische Sprachen, well-known in scholarship. But the new institution was to represent the colonial idea, and yet avoid being an isolated community of mediocre scientific character. The organization was effected by merging the various lectureships and institutes in Hamburg into a whole, under the patronage of Edmund Siemers and Alfred Beit, public-spirited citizens of the small republic. Characteristic of its spirit is the legend over the portal : Der Forschung, der I,ehre, der Bildung. 
The curriculum invades the province of the university in including philosophy, jurisprudence, political science, history and geography. Its main and characteristic work centres about the Seminars, groups of instructors, native assistants, and students with the books and apparatus pertaining to the lands and civilizations studied. Thus the Moslem Orient, Eastern Asia, and Africa form each a group. The phonetic laboratory serves them all ; and the German merchant marine co-operates in furnishing rare human materials for investigation from distant ports. At the other end of the scale we find courses in cooking and a variety of homely arts.

It is no matter of chance or of national endowment that German officials are in all the world proficient linguists, and often also men of scientific training. German commerce is the richer for these men. If they have a line of goods to sell or a message to carry, this is done without the continued friction which exists between ill-trained and untrained men and a foreign environment. Civil service is not in politics. Technical preparation is required beforehand. The hopeless are eliminated early with great economy and advantage to the service.

Language study is pursued under the following guiding principles : (1) As adults cannot learn languages quickly and thoroughly by mere imitation and little reasoning, as the child can and must do, grammar in the form of the classified observations of predecessors on the phenomenology of the language is indispensable. (2) Grammar in the sense of philology is the science of which linguistry is the art. It will not suffice to know about the languages; one must have a command of them. Immediate, intimate and prolonged contact with the living reality, abundant exercises for knitting up eye, ear, tongue, pen and action, are the means of making the foreign speech, like our own, a system of automatisms. instead of a repetition of tiring volitions. (3) A part of grammar muclı neglected is pronunciation. It is an indispensible part of the technique of linguistry. Its correlated science is phonetics. The actual phenomena of the learner's own speech and those of the foreign 
language must be studied. Then he may venture to learn by practice from the lips of a native. The learner and the native working alone and without training will not rise above stumbling and groping imitation. The European teacher must not be the model of pronunciation, but the native. He remains the interpreter of the one to the other. Also the pupil is often, and the native nearly always, unskilful in linguistic pedagogy. Where material fails one may use a phonographic record. Even where natives are available the machine does good service in the necessary endless repetitions. Started properly, the beginner will not fall into the habit of merely substituting the similar sounds of his own speech for the new ones.

It is obvious that men and women so trained are not only efficient in their own work, but lend their influence later to a progressive policy of administration. They keep in touch with the scientific work at home. Often they themselves publish valuable materials gathered in the foreign field.

The special workshop of phonetics in Hamburg, the Phonetisches Labartorium, was established by Professor Carl Meinhof, and put in charge of Dr. PanconcelliCalzia. The former is a phonetician and a well-known pioneer in African philology. The latter is a man of unique gifis and training, devoted to his subject in its widest aspects and applications. In the well-equipped laboratory in the quielest section of Hamburg, a community of interests has arisen among professions which before had hardly ever touched. All the normal and pathological phenomena of the voice in speech and song fall within its province. Linguists, teachers of the deaf and dumb, of singing and oratory, physicianis, psychologists, and practical people with special problems, visit it for research, instruction or inquiry. It has one method for all : observation, measurement, experiment, calculation, application.

To describe even cursorily the equipment of the laboratory would here be impossible. Parts of it, like the acoustic section and the kymographs, are familiar to the plyysicist; other purts are physiological and 
anatomical; and the throat specialist and the dentist would find many of his devices there also. There is a room for the glyphic apparatus of the phonograph and gramophone families, in which records are made and stored, and subjected to enlargement, microscopic examination, analysis and measurement. They also serve the more obvious purpose of recording the speech of such transients as are often procured from the Hagenbeck circus and the crews of the Asiatic and African ships, which return from long voyages to the home port of Hamburg. A Röntgen X-ray laboratory of special equipment and other photographic apparatus are housed in the basement. The personel consists of the director, a skilled general assistant, a servant, two instrument makers, a philologist, a teacher of voice, a teacher of the deaf and dumb, and a physician, the last four without pay. The State spares no pains to maintain the laboratory on the highest level of equipment and efficiency. It is not only serving through the colonial institute the practical ends of new candidates, but older men are coming back to Hamburg from the colonies to bring to it their problems and their materials. On one occasion Professor Meinhof was appealed to in despair by a group of missionaries who had utterly failed to master the language of the small and isolated community to which they had been sent. They asserted that there were very few words in the language, and that each word had a bewildering number of significations. Investigation showed that the seeming homonyms were distinguished by variations in the pitch of the voice. In another case a German, who had been born and had grown up among the fast disappearing inlabitants of an island in the South Pacific, was able to furnish unique materials for the study of humanity in that part of the world.

By keeping in closest touch with missionary communities, and by maintaining a systematic exchange of students, lecturers, reports, bibliography, and scientific materials, centres of study on the field-like that of Dr. Zwemer and the Rev. W. H. T. Gairdner, in Cairo-an almost ideal system may be evolved. It is of the greatest 
importance that those at home should constantly taste the atmosphere of the distant land; and it is obviously impossible to maintain libraries and professorships of university grade-to say nothing of laboratories-at great distances from the centres of Western civilization. The solution lies, as in every sort of training for service in foreign parts, in a syntliesis between the two ideas of outpost station and home university.

When the interest and generosity of Mrs. John S. Kennedy and other friends of Hartford Theological Seminary made possible the realization of a long-cherished plan of establishing in the city named, as part of a still larger scheme of religious education (see the Independent of October 30th, 1913), a school of spccial missionary preparation, the Hamburg Kolonialinstitut occupied a prominent place in the minds of its organizers. It seemed to them that men and women prepared in an institution of exacting scientific character and distinctly religious atmosphere, could not fail to affect profoundly the Mission abroad and to bring it into closer touch with the intellectual life at home. The Kennedy School of Missions is thus the first direct offspring of the Hamburg Institut on this side of the Atlantic. Steps have been taken to furnish instruction of the same character. The nucleus of a phonetic laboratory has been formed, and class-work initiated. It is hoped that the interest aroused by such a movement will penetrate into the wider circles of American language teaching. If phonetics never become an elementary study in the lower schools, as it well might do, it should influence the standpoint and method of all instruction in foreign languages and of English, not to mention the services it can render to the teachers of the deaf and dumb. No limitations have been placed upon the usefulness of this department, important and even primary as its application to missionary training will remain at the Hartford School.

Wilitam H. Worrell. 